\title{
The influence of construction and material solutions on the level of air tightness in single energy buildings
}

\author{
Artur Miszczuk ${ }^{1, *}$ \\ ${ }^{1}$ Warsaw University of Technology, Faculty of Civil Engineering, Institute of Civil Engineering, \\ Team Building and Sustainable Development Lecha Kaczynskiego 16, 00-637 Warsaw, Poland
}

\begin{abstract}
This publication focuses on the assessment of the impact of structural solutions of single-family buildings with an increased energy standard on their air-tightness level. The first part presents the threats resulting from the low tightness of the building. To formulate the conclusions, quantitative and qualitative casing tightness tests of existing single-family energy-efficient buildings were carried out. Construction and material solutions used in buildings were also analysed. The obtained results indicate that there is no impact of the building structure on its level of air tightness.
\end{abstract}

\section{Introduction}

The implementation of the principles of increasing the energy efficiency of buildings promoted in the world results in the need to minimize energy losses in buildings. Negative examples leading to the increase of the actual energy demand in relation to the design assumptions can be considered as too low level of air tightness of the building $[1,2]$. This dependence was presented, among others in the article [3], in which the authors prove that improving the tightness, in an energy efficiency building, may cause a $25 \%$ decrease in the demand for energy for heating and ventilation. The level of air infiltration is influenced by the number and size of critical places in the building envelope, construction materials used and combinations of components of different construction.

\section{The essence of determining the air tightness level of buildings}

The building's air tightness is defined as the number of air exchanges inside the building and flowing in an uncontrolled way through the gaps in the building envelope $\left(\mathrm{n}_{50}\right)$. Determination of air infiltration level is carried out at artificially induced pressure difference of $50 \mathrm{~Pa}$ [4]. The most frequently used measuring method is the "Blower Door test".

\footnotetext{
* Corresponding author: a.miszczuk@il.pw.edu.pl
} 
The low tightness of the building results in several risks both for its technical condition and the quality of the internal environment. It may lead to [5]: the appearance of inter-layer condensation of water vapor in the baffles; mold growth at the place of condensation; lowering the comfort of people staying indoors and increasing heating costs [6]; reducing the acoustic comfort of the rooms and the need to redesign the heating system together with increasing the power of heating devices.

There are many possibilities of creating sources of air infiltration, which result from the specificity of the construction of a given component or are caused by improper design of connections of individual elements constituting the building envelope. Uncontrolled air flow takes place through the building envelope in the place of leakage, such as: cracks, gaps and other unintentional holes [4].

To detect the locations of infiltration, one of three methods are most commonly used, including the following: hand surface (under pressure) [7]; smoke devices [8] or thermal imaging cameras (under pressure) $[9,10]$. The most accurate of them, however, is the method of thermal imaging that allows not only to detect the place of uncontrolled air flow, but also to determine the approximate size of the leak.

In the case of a 2-storey, single-family residential building, the share of losses related to infiltration can reach up to $30 \%$ of the total energy demand. [11]. In another study [12], the maximum share of losses related to infiltration in total losses was estimated at $40 \%$.

The influence of uncontrolled air flow on the demand for heating power was confirmed by the author of the study [13], indicating that in the case of tightness at the level $\mathrm{n}_{50}=1.5 \mathrm{~h}^{-1}$, the installed power increases by $2.9 \mathrm{~kW}$. If the level $\mathrm{n}_{50}=0.75 \mathrm{~h}^{-1}$, the increase in power is $1.9 \mathrm{~kW}$, and when $\mathrm{n}_{50}=0.50 \mathrm{~h}^{-1}$ - by $1.0 \mathrm{~kW}$. However, the author of the study does not provide information about which building the above-mentioned quantities refer to and what the reference level is.

\section{Conducted Research}

Striving to achieve an increasingly high energy efficiency standard in construction, in the context of air-tightness of newly designed buildings, has contributed to the formulation of a research task. It was aimed at finding the relationship between construction and material solutions of buildings and their level of air tightness in as many buildings erected in Poland as possible in $1997-2015$. The research was conducted on a total of 24 residential and single-family buildings. They concerned only facilities for which owners, investors or developers assumed at the design stage that they would be erected in an energy-saving or passive standard.

At the initial stage, before the research was carried out, the methodology for selecting buildings in terms of their location, type, construction, number of storeys, type of ventilation and the year of putting into use was elaborated. Objects analysed had to meet certain minimum requirements. These should be buildings:

- $\quad$ single-family houses. The type of building was selected since according to statistical surveys carried out by the Central Statistical Office [14], they constitute most of residential buildings in Poland;

- equipped with mechanical ventilation with heat recovery (recuperate), since to a significant extent, its use reduces heat loss for heating ventilation air;

- located in possibly different places in Poland. This allows you to reduce the likelihood of building and finishing objects by the same construction brigades. 
Table 1. Summary of basic information about the tested buildings

\begin{tabular}{|c|c|c|c|c|c|}
\hline no. & city & building indication & $\begin{array}{c}\text { number of } \\
\text { storeys }\end{array}$ & $\begin{array}{c}\mathrm{A} / \mathrm{V} \\
\text { factor } \\
{\left[\mathrm{m}^{-1}\right]}\end{array}$ & $\begin{array}{c}\mathbf{n}_{50} \\
{\left[\mathbf{h}^{-1}\right]}\end{array}$ \\
\hline 1 & Czestochowa & $\mathrm{C}-1$ & 2 & 0,83 & 3,29 \\
\hline 2 & \multirow{2}{*}{ Gdansk } & G-1 & 1 & 0,87 & 3,04 \\
\hline 3 & & G-2 & 3 & 0,62 & 0,83 \\
\hline 4 & Kluczbork & K-1 & 2 & 0,69 & 0,17 \\
\hline 5 & Kolo & K-2 & 2 & 0,78 & 0,77 \\
\hline 6 & \multirow{5}{*}{ Lublin } & L-1 & 1 & 0,94 & 2,53 \\
\hline 7 & & L-2 & 1 & 0,98 & 1,95 \\
\hline 8 & & L-3 & 1 & 0,84 & 0,64 \\
\hline 9 & & L-4 & 1 & 0,89 & 3,58 \\
\hline 10 & & L-5 & 2 & 0,71 & 0,56 \\
\hline 11 & \multirow{2}{*}{ Olsztyn } & O-1 & 3 & 0,66 & 1,58 \\
\hline 12 & & $\mathrm{O}-2$ & 1 & 0,97 & 2,24 \\
\hline 13 & Pila & $\mathrm{P}-1$ & 2 & 0,72 & 0,45 \\
\hline 14 & \multirow{2}{*}{ Poznan } & $\mathrm{P}-2$ & 2 & 0,71 & 0,55 \\
\hline 15 & & $\mathrm{P}-3$ & 1 & 0,75 & 1,78 \\
\hline 16 & Katowice & S-1 & 1 & 0,86 & 1,5 \\
\hline 17 & \multirow{2}{*}{ Tarnowskie Gory } & $\mathrm{T}-1$ & 2 & 0,75 & 4,02 \\
\hline 18 & & $\mathrm{~T}-2$ & 2 & 0,75 & 3,62 \\
\hline 19 & \multirow{5}{*}{ Warszawa } & $\mathrm{W}-1$ & 2 & 0,70 & 5,33 \\
\hline 20 & & $\mathrm{~W}-2$ & 1 & 1,02 & 4,74 \\
\hline 21 & & W-3 & 1 & 0,87 & 0,86 \\
\hline 22 & & W-4 & 2 & 0,82 & 3,55 \\
\hline 23 & & $\mathrm{~W}-5$ & 1 & 0,94 & 0,63 \\
\hline 24 & Wroclaw & W-6 & 1 & 0,75 & 3,46 \\
\hline
\end{tabular}

The shape ratio of the analysed buildings (ratio $\mathrm{A}$ - area of the building envelope to $\mathrm{V}$ gross volume of the heated part) varied (table 1) and ranged from $0.62 \mathrm{~m}^{-1}$ for the building, the most compact (G-2) to $1,02 \mathrm{~m}^{-1}(\mathrm{~W}-2)$. The average $\mathrm{A} / \mathrm{V}$ value was $0.81 \mathrm{~m}^{-1}$.

The study includes buildings that differ in terms of the construction of external partitions (table 2). The largest group were buildings with a masonry construction of external

(13 buildings). There were fewer objects with skeletal structure (6 buildings) and technology of lost formwork (5 buildings). 
Table 2. Information about the construction, materials and technologies used on tested buildings.

\begin{tabular}{|c|c|c|c|c|c|}
\hline no. & $\begin{array}{c}\text { building } \\
\text { indication }\end{array}$ & $\begin{array}{c}\text { attic } \\
\text { type }\end{array}$ & $\begin{array}{c}\text { construction } \\
\text { of external } \\
\text { walls }\end{array}$ & $\begin{array}{c}\text { roof/ceiling/ } \\
\text { flat roof } \\
\text { construction }\end{array}$ & $\begin{array}{c}\text { foundation } \\
\text { construction }\end{array}$ \\
\hline 1 & $\mathrm{C}-1$ & $\mathrm{Cz}, \mathrm{NN}$ & $\mathrm{Sz}, \mathrm{WM}$ & $\mathrm{Sz}, \mathrm{WM}$ & $\mathrm{BLF}$ \\
\hline 2 & $\mathrm{G}-1$ & $\mathrm{Br}$ & $\mathrm{BS}$ & $\mathrm{Sz}, \mathrm{WM}$ & $\mathrm{ZPF}$ \\
\hline 3 & $\mathrm{G}-2$ & $\mathrm{OU}$ & $\mathrm{BS}$ & $\mathrm{Sz}, \mathrm{WM}$ & $\mathrm{ZPF}$ \\
\hline 4 & $\mathrm{~K}-1$ & $\mathrm{OU}$ & $\mathrm{BS}$ & $\mathrm{Sz}, \mathrm{WM}$ & $\mathrm{ZPF}$ \\
\hline 5 & $\mathrm{~K}-2$ & $\mathrm{Cz}, \mathrm{NN}$ & $\mathrm{Sz}, \mathrm{PP}$ & $\mathrm{Sz}, \mathrm{PP}$ & $\mathrm{BLF}$ \\
\hline 6 & $\mathrm{~L}-1$ & $\mathrm{NN}$ & $\mathrm{P}$ & $\mathrm{Sz}, \mathrm{WM}$ & $\mathrm{BLF}$ \\
\hline 7 & $\mathrm{~L}-2$ & $\mathrm{NN}$ & $\mathrm{BK}$ & $\mathrm{Sz}, \mathrm{WM}$ & $\mathrm{ZPF}$ \\
\hline 8 & $\mathrm{~L}-3$ & $\mathrm{NN}$ & $\mathrm{ST}$ & $\mathrm{BG}$ & $\mathrm{ZPF}$ \\
\hline 9 & $\mathrm{~L}-4$ & $\mathrm{NN}$ & $\mathrm{ST}$ & $\mathrm{BG}$ & $\mathrm{ZPF}$ \\
\hline 10 & $\mathrm{~L}-5$ & $\mathrm{NN}$ & $\mathrm{ST}$ & $\mathrm{BG}$ & $\mathrm{ZPF}$ \\
\hline 11 & $\mathrm{O}-1$ & $\mathrm{Cz}, \mathrm{NN}$ & $\mathrm{BK}$ & $\mathrm{Sz}, \mathrm{WC}$ & $\mathrm{BLF}$ \\
\hline 12 & $\mathrm{O}-2$ & $\mathrm{NN}$ & $\mathrm{Sz}, \mathrm{WC}$ & $\mathrm{Sz}, \mathrm{WC}$ & $\mathrm{ZPF}$ \\
\hline 13 & $\mathrm{P}-1$ & $\mathrm{OU}$ & $\mathrm{Sz}, \mathrm{WC}$ & $\mathrm{Sz}, \mathrm{WC}$ & $\mathrm{BLF}$ \\
\hline 14 & $\mathrm{P}-2$ & $\mathrm{Cz}, \mathrm{NN}$ & $\mathrm{BS}$ & $\mathrm{Sz}, \mathrm{WM}$ & $\mathrm{ZPF}$ \\
\hline 15 & $\mathrm{P}-3$ & $\mathrm{Br}$ & $\mathrm{BS}$ & $\mathrm{Str}$ & $\mathrm{ZPF}$ \\
\hline 16 & $\mathrm{~S}-1$ & $\mathrm{Br}$ & $\mathrm{P}$ & $\mathrm{Sz}, \mathrm{WM}$ & $\mathrm{BLF}$ \\
\hline 17 & $\mathrm{~T}-1$ & $\mathrm{Cz}, \mathrm{NN}$ & $\mathrm{ST}$ & $\mathrm{Sz}, \mathrm{WM}$ & $\mathrm{ZPF}$ \\
\hline 18 & $\mathrm{~T}-2$ & $\mathrm{Cz}, \mathrm{NN}$ & $\mathrm{ST}$ & $\mathrm{Sz}, \mathrm{WM}$ & $\mathrm{ZPF}$ \\
\hline 19 & $\mathrm{~W}-1$ & $\mathrm{Br}$ & $\mathrm{BS}$ & $\mathrm{BG}$ & $\mathrm{BLF}$ \\
\hline 20 & $\mathrm{~W}-2$ & $\mathrm{Br}$ & $\mathrm{BK}$ & $\mathrm{Sz}, \mathrm{WM}$ & $\mathrm{BLF}$ \\
\hline 21 & $\mathrm{~W}-3$ & $\mathrm{NN}$ & $\mathrm{BK}$ & $\mathrm{Sz}, \mathrm{WM}$ & $\mathrm{BLF}$ \\
\hline 22 & $\mathrm{~W}-4$ & $\mathrm{Br}$ & $\mathrm{Sz}, \mathrm{WM}$ & $\mathrm{Sz}, \mathrm{WM}$ & $\mathrm{BLF}$ \\
\hline 23 & $\mathrm{~W}-5$ & $\mathrm{Br}$ & $\mathrm{Sz}, \mathrm{WM}$ & $\mathrm{Sz}, \mathrm{WM}$ & $\mathrm{BLF}$ \\
\hline 24 & $\mathrm{~W}-6$ & $\mathrm{Cz}, \mathrm{NN}$ & $\mathrm{BK}$ & $\mathrm{Sz}, \mathrm{WM}$ & $\mathrm{BLF}$ \\
\hline $\mathrm{Sign}$ & & & & & \\
\hline 5 & & & & \\
\hline
\end{tabular}

Signs:

- attic type: $\mathrm{Br}$ - no attic in the building; $\mathrm{Cz}$ - attic over the building; $\mathrm{NN}$ - attic unheated and unheated; OU - attic and heated attic;

- construction of external walls: BK - brick structure made of cellular concrete blocks; BS - brick construction made of silicate blocks; P brick construction of Porotherm ceramic airbricks; ST - partition in the lost formwork technology (formwork made of a styrofoam insulating material with a supporting core made of reinforced concrete); $\mathrm{Sz}$ frame construction; PP - thermal insulation from polyurethane foam; WC - thermal insulation of cellulose wool; WM - thermal insulation from mineral wool;

- construction of the roof/flat roof/ceiling of the top storey: BG concrete ribbed ceiling; Str - strop concrete ceiling; Sz - frame structure of the partition; PP - thermal insulation from polyurethane foam; WC thermal insulation of cellulose wool; WM - thermal insulation from mineral wool;

- foundation construction: BLF - strip foundation; ZPF - slab foundation; 


\section{Finding the relationship between tightness and building properties}

Leak tests of buildings have been carried out in accordance with the applicable PN-EN 13829:2002 standard [15]. On their basis, it was found that the value of $n_{50}$ coefficient varied widely and amounted from $0.17 \mathrm{~h}^{-1}$ for building $\mathrm{K}-1$ to $5,33 \mathrm{~h}^{-1}$ for building W-1 (Table 1, Figure 1). Requirements set by NFOSiGW regarding the level of air tightness

of energy-efficient buildings NF40 $\left(\mathrm{n}_{50} \leq 1.0 \mathrm{~h}^{-1}\right)$ [16] have been met by 9 buildings (Q-1, P-1, P-2, L-5, W-5, L -3, K-2, G-2 and W-3), while for passive objects NF15 $\left(\mathrm{n}_{50} \leq 0.6 \mathrm{~h}^{-1}\right)$ [16], they were met by 4 buildings (Q-1, P-1, P -2 and L-5).

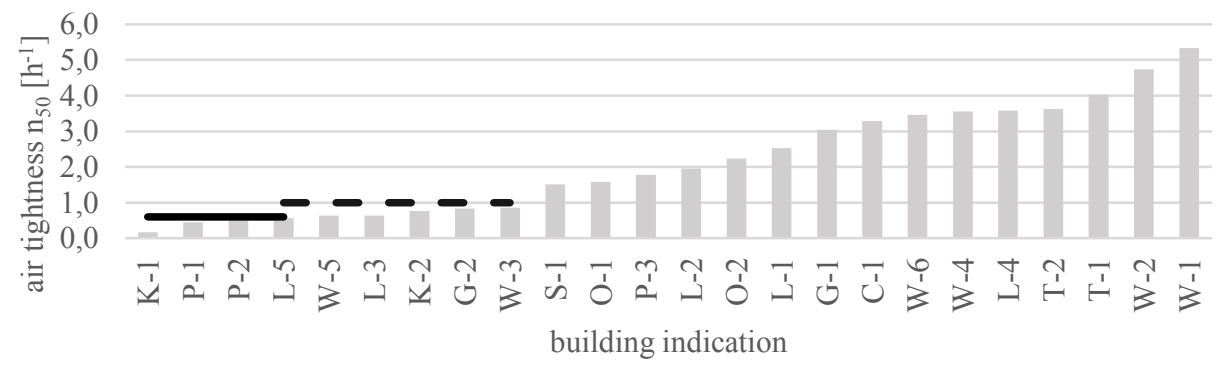

- passive building (NF15) _ - - energy-efficient buildings (NF40)

Fig. 1. List of $\mathrm{n}_{50}$ values obtained for the examined buildings.

During tests, the thermal imaging camera was used to identify the locations of uncontrolled air flow through the building envelope (with artificially created under pressure). The locations of air infiltration are shown in blue on thermographic images (examples of such places are shown in Figure 2 and Figure 3).

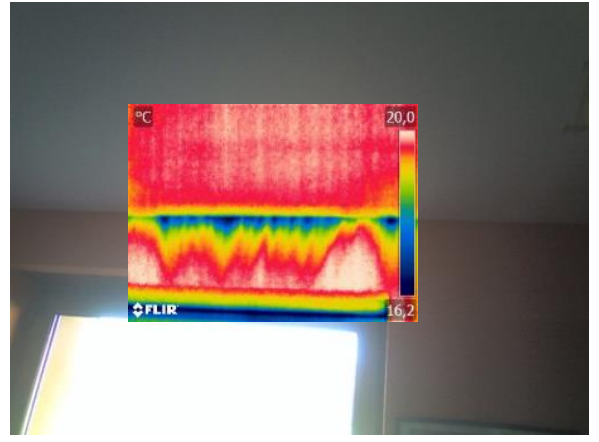

Fig. 2. Traditional and thermographic photo of leaks at the connection of the ceiling with the external wall [17].

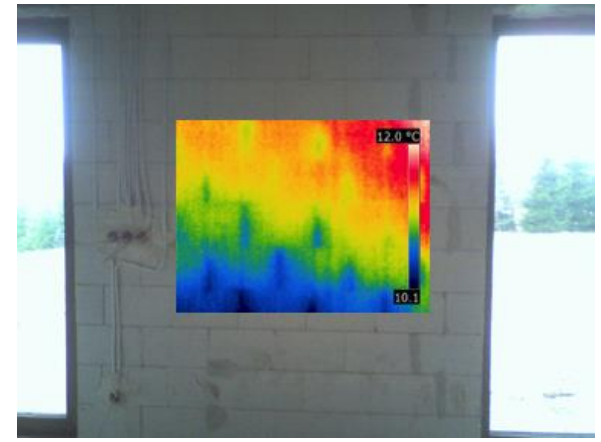

Fig. 3. Traditional and thermographic picture of leaks at the combination of silicate blocks in the external wall [17].

The carried-out analysis of building designs and studies using the Blower Door test with the simultaneous use of a thermal imaging camera made it possible to compile a list of the tightness of the building against the construction and material solutions of the building. 
There is no visible dependence at the comparison of the building envelope with the type of attic (Figure 4). The $\mathrm{n}_{50}$ values in the scope of a given solution are varied. By comparison the highest air tightness with the lowest tightness of buildings within the given attic type, the sizes $n_{50}$ differ from 5 (for attics and heated attic) to over 8 times (in the absence of an attic).

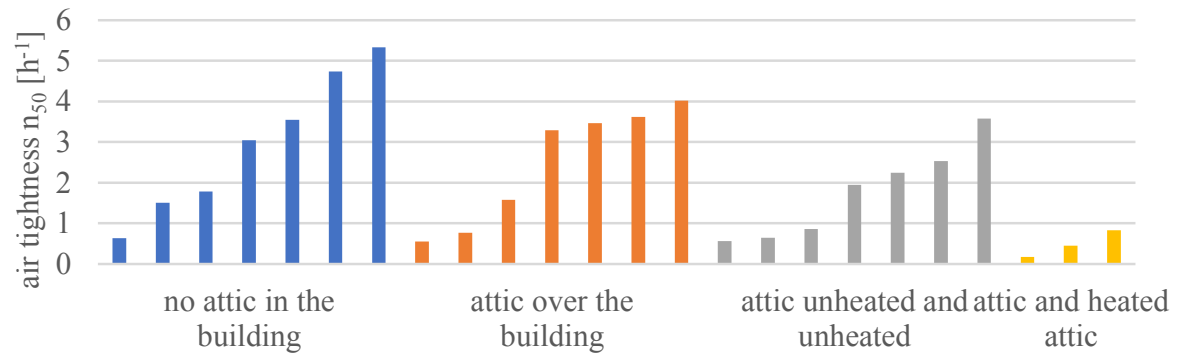

Fig. 4. Air-tightness depending on the attic type.

The second set (Figure 5) concerned wall construction materials. In this case, there is also no visible dependency. The values of the $n_{50}$ coefficient for a given constructional solution are varied and range from about 2 (for external walls from ceramic hollow bricks) to more than 31 times (for silicate blocks).

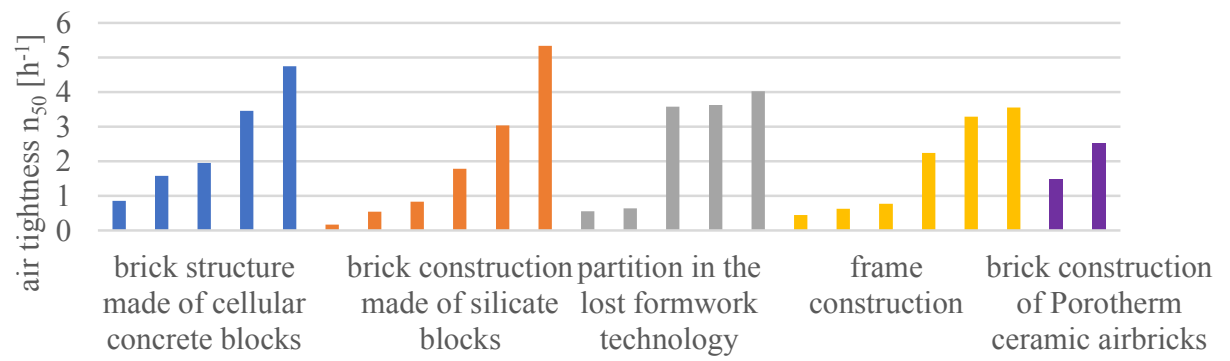

Fig. 5. Air tightness of the building depending on the design of external walls.

At the combination of various types of roof/ceiling/flat roof structure (Figure 6) with the air tightness level of the building, there is no visible dependence. In the case of the most common structural solution (Sz, WM - skeleton structure with mineral wool filling) $\mathrm{n}_{50}$ values are different (they range from $0.17 \mathrm{~h}^{-1}$ to $4.74 \mathrm{~h}^{-1}$ ).

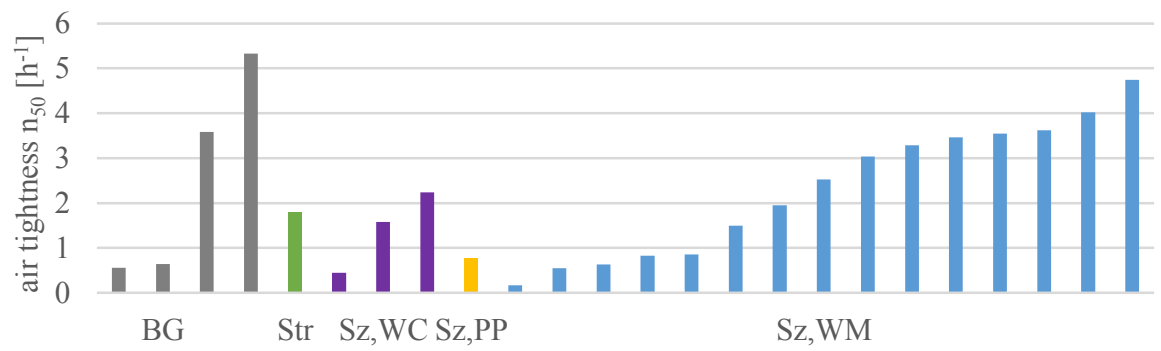

Fig. 6. Air tightness of the building depending on the roof/ceiling structure. BG- concrete, coarsegrained, Str - prestressed concrete, Sz - skeleton structure (WC-cellulose wool, PP-polyurethane foam, WM-mineral wool). 
There is also no visible relationship between the tightness of the building and the construction of its foundation (Figure 7). For each of the solutions, the $n_{50}$ values determined for the building are very diverse. From $0.45 \mathrm{~h}^{-1}$ to $5.33 \mathrm{~h}^{-1}$ for strip foundation and from $0.17 \mathrm{~h}^{-1}$ to $4.02 \mathrm{~h}^{-1}$ for reinforced slab foundation.

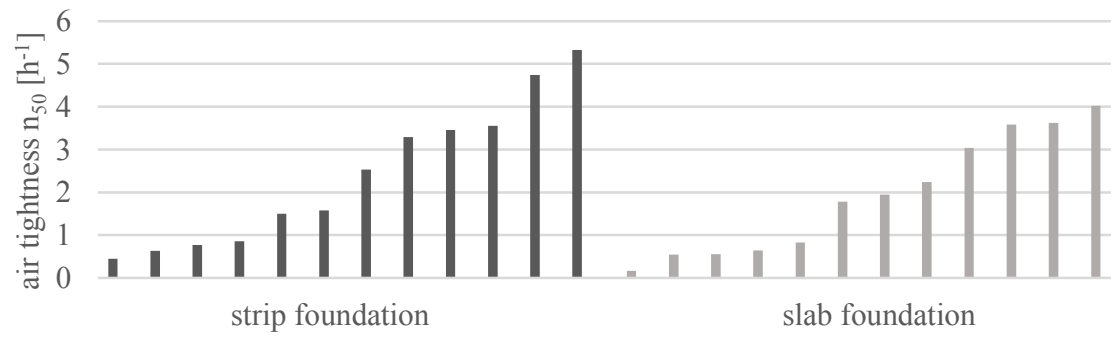

Fig. 7. Air tightness of the building depending on the foundation construction.

An analysis of the length of the horizontal edges of the partitions (connection of the external wall with the roof/flat roof and walls with the foundation slab/strip) with the building's tightness was also carried out, it did not indicate any relationship between these two variables (Figure 8). Only the corners were considered for the analysis in case of a combination of 2 different technologies (e.g. connection of a lightweight framework with a brick or monolithic structure). Interestingly, the highest $\mathrm{n}_{50}$ value was obtained for the building, in which there is the largest connection length of partitions with different construction.

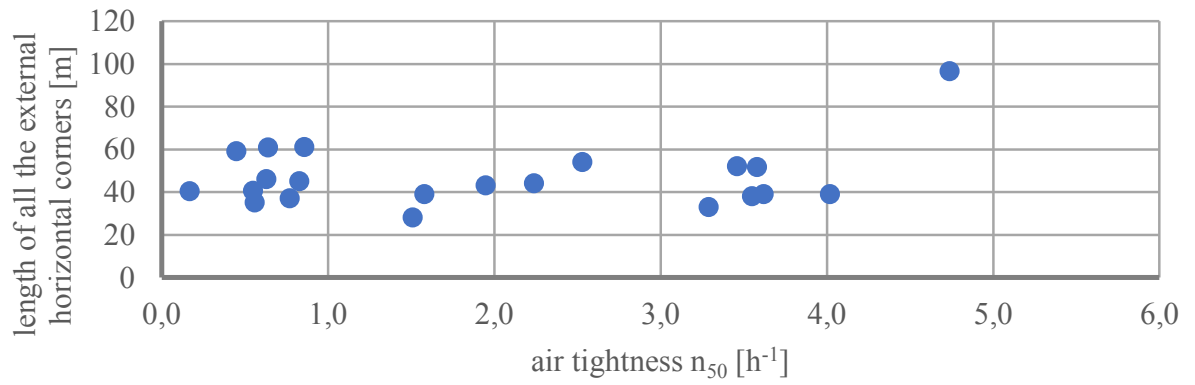

Fig. 8. Air tightness of the building depending on the length of the external horizontal corners in the building

Based on the presented tables, there are other reasons that increase the $n_{50}$ value. It is most likely that the human factor, the insufficient knowledge of many designers and building contractors, as well as the inaccuracy of air-tight coatings have a negative effect on the air tightness.

\section{Summary and conclusions}

The analysed buildings had various constructions and building materials. Based on the results of the tests and analyses carried out, the relationship between the air tightness of the building and the construction and material solutions cannot be found. There are also no direct correlations between the tightness and the length of the connections of the external partitions. It can be stated that in practice, air tightness is a function of many, not one, variable related to the geometry and size of the building. However, certain values assumed at the design stage of the object as well as geometrical parameters do not have to translate 
directly into the resulting air tightness. However, the important factor is the design of components and the way they are assembled. This is confirmed by the results obtained from the leak proof list depending on the average heat transfer coefficient of the external partitions $\mathrm{U}_{\text {sr.waz. }}[18,19]$.

The building's tightness should be approached comprehensively. The process of achieving a certain building integrity begins at the stage of building design, during which appropriate materials ensuring high air tightness of the building should be adopted. It should be checked that the design and material assumptions have been implemented during the construction of the building. Without proper design of the air-tight layer and control during the construction of the building, it is not possible to achieve high tightness of the building.

\section{References}

1. A.M. Egan, 12th Conference of International Building Performance Simulation Association, Sydney (2011)

2. G. Villi, C. Peretti, S. Graci, M. De Carli, Journal of Building Performance Simulation, 7, 98-118 (2012)

3. K. Nowak, K. Nowak-Dzieszko, Materiały Budowlane, 1, 24-26 (2014)

4. G. Martin, Dictionary of Construction, Surveying, and Civil Engineering (Oxford University Press, 2012)

5. A. Miszczuk, Procedia Engineering, 153, 461-466 (2016)

6. S. Roaf, Ecohouse (Oxford, Elsevier, 2007)

7. A. Alsabry, J. Zurawski, Izolacje, 10, 84-86 (2010)

8. P. Waterfield, The Energy Efficient Home: A Complete Guide (Ramsbury, The Crowood Press, 2011)

9. P. Krause, Szczelność obudowy a ochrona cieplna budynku, Fizyka Budowli w Teorii i Praktyce, 2, pp. 147--150, (2007)

10. H. Nowak, Zastosowania badań termowizyjnych w budownictwie (Wrocław, Oficyna Wydawnicza Politechniki Wroclawskiej, 2012)

11. E. Allen, A. C. Schreyer, Fundamentals of Residential Construction (New Jersey, John Wiley \& Sons, 2011)

12. J. Milczarek, Materiały Budowlane, 1, 38 (2015)

13. K. Hall, R. Nicholls, The Green Building Bible, 2 (Llandysul, Green Building Press, 2008)

14. GUS, Zamieszkane Budynki Narodowy Spis Powszechny Ludności i Mieszkań 2011 (Warszawa, GUS, 2013)

15. PN-EN 13829:2002; Właściwości cieplne budynków - Określanie przepuszczalności powietrznej budynków - Metoda pomiaru ciśnieniowego z użyciem wentylatora

16. Program Priorytetowy: Poprawa efektywności energetycznej Cześć 2) Dopłaty do kredytów na budowę domów energooszczędnych, NFOŚiGW (2015)

17. A. Miszczuk, Traditional and thermovision photographs made as part of scientific research, grants no.: 504M10884083 and 504M10881405, (2013-2015)

18. A. Miszczuk, MATEC Web of Conferences, 117, 1-8 (2017)

19. A. Miszczuk, K. H. Żmijewski, Materiały Budowlane, 1, 24-27 (2015) 